\title{
PENGUKURAN KONSERVATISME AKUNTANSI: SEBUAH LITERATUR REVIEW
}

\author{
Anggita Langgeng Wijaya \\ Pendidikan Akuntansi IKIP PGRI Madiun \\ Gonggeng14@gmail.com
}

\begin{abstract}
This research is a study of the literature that discusses the measurement of accounting conservatism. Research about accounting conservatism raises several alternative methods that can be used to measure the level of accounting conservatism in a company. With reference to some previous literature it can be conclude that conservatism can be measured by several methods, including: 1) the market model of Basu (1997), 2) market to book ratio approach, 3) operating income approach, 4) the accrual of cash flow approach, 5) non-operating accrual approach.
\end{abstract}

Key word: accruals, cash flow, accounting conservatism, measurement.

\begin{abstract}
ABSTRAK
Penelitian ini merupakan studi literatur yang membahas tentang pengukuran konservatisme akuntansi. Semakin berkembangnya penelitian tentang konservatisme akuntansi memunculkan beberapa alternatif metoda yang dapat digunakan untuk mengukur tingkat konservatisme akuntansi dalam sebuah perusahaan. Dengan mengacu pada beberapa literatur sebelumnya dapat disimpulkan bahwa konservatisme dapat diukur dengan beberapa metoda,antara lain: 1) model pasar Basu (1997), 2). model market to book ratio, 3) pendekatan laba operasi, 4) pendekatan akrual arus kas, 5) pendekatan non operating acrual.
\end{abstract}

Kata kunci : akrual, arus kas, konservatisme akuntansi, pengukuran.

\section{PENDAHULUAN}

Konservatisme akuntansi merupakan salah satu topik yang kontroversial dan menjadi perdebatan dalam penelitian akuntansi. Watts (2003) menyatakan bahwa secara tradisional konservatisme dapat diartikan sebagai perilaku yang mengantisipasi tidak adanya profit dan mengantisipasi semua kemungkinan rugi. Konservatisme merupakan prinsip akuntansi yang penerapannya akan menyebabkan angka laba dan aset menjadi rendah dan biaya dan hutang menjadi tinggi. Konservatisme adalah eatimasi dan metoda yang penerapannya akan membuat nilai bersih aktiva relatif rendah (Penman dan Zhang, 2002). Basu (1997) menginterpretasikan konservatisme sebagai kecendurungan akuntan menggunakan tingkat verifikasi yang lebih tinggi untuk mengakui good news sebagai keuntungan dibanding mengakui bad news sebagai kerugian. Perbedaan pengakuan terhadap kedua informasi laba menyebabkan asymetric timeliness karena perbedaan sensitifitas laba terhadap bad news dan good news.

Konservatisme merupakan konsep akuntansi yang menuai banyak kritik. Kiryanto dan Supriyanto (2006) mengatakan bahwa laporan keuangan yang disusun 
berdasarkan metode yang konservatif akan cenderung bias karena tidak mencerminkan kondisi perusahaan yang sesungguhnya. Hal tersebut memunculkan keraguan tentang manfaat dari laporan keuangan yang disusun berdasarkan akuntansi yang konsevatif. Paek et al (2007) menyebutkan bahwa konservatisme akan menyebabkan terjadinya miss-maching dimana biaya masa depan di-machingkan dengan pendapatan saat ini. Idealnya biaya yang terjadi para periode ini akan di-machingkan dengan pendapatan pada periode yang sama. Miss-maching tersebut akan menyebabkan understatement terhadap laba dalam perioda kini yang dapat mengarahkan pada overstatement terhadap laba dalam perioda-perioda berikutnya yang disebabkan oleh understatement terhadap biaya pada perioda tersebut.

Fala (2007) menyatakan bahwa pihak yang mendukung konservatisme menyatakan bahwa penerapan akuntansi konservatif akan menghasilkan laba yang berkualitas karena prinsip ini mencegah perusahan untuk membersar-besarkan laba dan membantu pengguna laporan keuangan dengan menyajikan laba dan aktiva yang tidak overstate. Givoly dan Hayn (2000) menjelaskan bahwa dalam satu dekade terkahir terdapat peningkatan penggunaan laporan keuangan yang konservatif pada perusahaanperusahaan di Amerika, hal tersebut membuktikan meskipun banyak pihak yang mengkritik namun konservatisme akuntansi masih dipandang sebagai metoda yang bermanfaat bagi para pemakai laporan keuangan.

Penman dan Zhang (2002) menyatakan bahwa penerapan konservatisme akuntansi tidak hanya berdampak pada neraca perusahaan namun juga berdampak pada angka-angka yang dilaporkan dalam laporan laba rugi perusahaan. Perusahaan yang menerapkan konservatisme akuntansi akan melaporkan laba yang lebih rendah jika dibandingkan dengan perusahaan yang menerapkan akuntansi liberal. Lo (2005) menyatakan bahwa implikasi akuntansi konservatif pada perusahaan tercermin dalam aktivitas operasional perusahaan diantaranya : (1) memperlambat pengakuan revenues, (2) mempercepat pengakuan expenses, (3) merendahkan penilaian aktiva, dan (4) meninggikan penilaian utang. Hal tersebut akan menjadikan nilai aktiva bersih perusahaan menjadi rendah.

Berkembangnya penelitian tentang konservatisme akuntansi memunculkan berbagai macam metoda yang digunakan untuk mengukur konservatisme akuntansi. Hal tersebut membuat peneliti tertarik untuk membahas tentang beberapa metoda yang digunakan untuk mengukur konservatisme akuntansi dengan mengacu pada beberapa peleitian terdahulu. Hasil penelitian ini diharapkan dapat membantu para peneliti yang akan meneliti tentang konservatisme akuntansi terutama tentang metoda pengukuran konservatisme akuntansi.

\section{PENGUKURAN KONSERVATISME}

Prinsip akuntansi yang berlaku umum (PABU) memberikan fleksibilitas bagi manajemen dalam menentukan metode maupun estimasi akuntansi yang dapat digunakan. Fleksibilitas tersebut akan mempengaruhi perilaku manajer dalam melakukan pencatatan akuntansi dan pelaporan transaksi keuangan perusahaan. Dalam kondisi keragu-raguan, seorang manajer harus menerapkan prinsip akuntansi yang bersifat konservatif (Wardhani, 2008). Kiryanto dan Supriyanto (2006) menjelaskan bahwa definisi akuntansi konservatif umum yang digunakan bahwa akuntan harus melaporkan informasi akuntansi yang terendah dari beberapa kemungkinan nilai untuk aktiva dan pendapatan serta yang tertinggi dari beberapa kemungkinan nilai kewajiban dan beban. 
Widay (2004) melakukan penelitian mengenai faktor-faktor yang mempengaruhi pilihan perusahaan terhadap akuntansi konservatif. Dalam analisisnya digunakan empat asumsi untuk mengkategorikan sebuah perusahaan dikatakan menerapkan akuntansi konservatif. Empat asumsi tersebut antara lain :

1. Dilihat dari metoda pencatatan persediaan, perusahaan yang menggunakan FIFO atau average akan menghasilkan laporan keuangan yang lebih konservatif menujukan dibandingkan dengan metoda LIFO. Dengan asumsi ekonomi dalam keadaan inflasi. Metoda persediaan average lebih konservatif jika dibandingkan dengan metoda persediaan FIFO.

2. Dilihat dari metoda penyusutan yang digunakan maka perusahan dengan metoda double declaning methods akan menghasilkan laporan keuangan yang lebih konservatif jika dibandingkan dengan metoda garis lurus karena akan menghasilkan kos yang lebih tinggi.

3. Dilihat dari perioda amortitasi, perusahaan dengan metoda amortitasi yang lebih pendek menunjukan perusahaan tersebut konservatif. Perioda amortisasi yang panjang menunjukan perusahan menerapkan akutansi optimis.

4. Dilihat dari pengakuaan terhadap biaya riset dan pengembangan. Bila biaya riset dan pengembangan diakui sebagai kos pada perioda berjalan maka perusahaan akan menghasilkan laporan keuangan yang konservatif jika dibandingkan bila perusahaan mencatata biaya riset sebagai aktiva.

Lebih lanjut dijelaskan bahwa perusahaan yang memenuhi dua dari empat asumsi di atas maka perusahaan tersebut dikatakan konservatif. Sedangkan secara empiris beberapa penelitian terdahulu telah mengembangkan beberapa model yang dapat digunakan sebagai proksi konservatisme akuntansi, antara lain :

1. Model Basu (1997)

Menurut Basu (1997) konservatisme diukur dengan pendekatan reaksi pasar atas informais yang diungkapkan perusahaan. Konservatisme dikukur dengan cara membentuk regresi antara return saham terhadap laba (Basu, 1997). Konservatisme dihitung dengan rumus :

$\mathrm{NI}=\beta 0+\beta 1 \mathrm{NEG}+\beta 2 \mathrm{RET}+\beta 3 \mathrm{RET}^{*} \mathrm{NEG}+\mathrm{e}$

Keterangan :

NI = Laba per lembar saham i tahun $\mathrm{t}$

RET $=$ Return saham $\mathrm{i}$ tahun $\mathrm{t}$

NEG = variabel dummy dimana (1) apabila return negatif, (0) apabila return positif.

$\beta_{1}-\beta_{2}=$ Slope Regresi

$\beta_{3} \quad=$ Proksi konservatisme, apabila bertanda positif hal tersebut menunjukan bahwa perusahaan menerapkan akuntansi konservatif.

Menurut metoda di atas, maka sebuah perusahaan dikatakan menerapkan konservatisme akuntansi apabila $\beta_{3}$ sebagai interaksi antara Return saham i tahun $t$ dan dummy variabel return menunjukkan hasil positif. Hal ini didasarkan pada asumsi pasar dimaka pasar saham lebih cepat berekasi terhadap bad news dari pada good news.

2. Market to book ratio mengacu Givoly dan Hayn (2000). Rasio ini merupakan perbandingan antara nilai pasar ekuitas dengan nilai buku ekuitas.dinotasikan dengan rumus :

$\mathrm{M} / \mathrm{B}=\frac{\text { Market Value of Common Equity }}{\text { Book Value of Common Equity }}$ 
Rasio dengan nilai lebih besar dari satu mengindikasikan penerapan akuntansi konservatif. Hal ini didasari pemikiran bahwa nilai Market to book ratio lebih besar dari satu menunjukkan bahwa perusahaan mengakui nilai buku perusahaan lebih kecil dari nilai pasar perusahaan.

3. Negatif earning response coefficient dari perubahan laba operasi mengacu pada Paek et al (2007). Dirumuskan dengan persamaan model regresi sebagai berikut :

$\Delta \mathrm{OI}_{\mathrm{t}}=\mathrm{d} 0 \mathrm{t}+\mathrm{d} 1 \mathrm{t} \mathrm{DOI}_{\mathrm{t}-1}+\mathrm{d} 2 \mathrm{t} \Delta \mathrm{OI}_{\mathrm{t}-1}+(-\mathrm{CON} 3 \mathrm{t}) \mathrm{DOI}_{\mathrm{t}-1} * \Delta \mathrm{OI}_{\mathrm{t}-1+\mathrm{e}}$

Keterangan :

$\Delta \mathrm{OI}_{\mathrm{t}} \quad=$ Perubahan Operating Income pada tahun $\mathrm{t}$

DOI $_{\mathrm{t}-1} \quad=$ variabel dummy dengan (1) bila perubahan laba operasi negatif, $(0)$ untuk perubahan laba operasi positif.

$\Delta \mathrm{OI}_{\mathrm{t}-1} \quad=$ Perubahan Operating Income pada tahun $\mathrm{t}-1$

$\mathrm{DOI}_{\mathrm{t}-1} * \Delta \mathrm{OI}_{\mathrm{t}-1}=$ Interaksi antara Perubahan Operating Income pada tahun $\mathrm{t}-1$ dengan variabel dummy

$-\mathrm{CON}_{3 \mathrm{t}}=$ Proksi konservatisme, Bila nilai koefisien negatif menunjukan perusahaan menerapkan akuntansi konservatif.

4. Membentuk regresi antara arus kas operasi dan akrual perusahaan mengacu pada Paek et al (2007). Dirumuskan dengan persamaan regresi sebagai berikut :

$\mathrm{ACC} t \mathrm{t}=\mathrm{e} 01+\mathrm{e} 1 \mathrm{t} \mathrm{DCFO} t+\mathrm{e} 2 \mathrm{t} \mathrm{DCFO} t+\mathrm{CON} 4 \mathrm{t} \mathrm{DCFO} * \mathrm{CFO}+\mathrm{e}$

Keterangan :

ACCt $=$ Operating Income dikurangi dengan arus kas operasi perusahaan dibagi dengan total aset perusahaan

DCFOt = variabel dummy untuk arus kas operasi dimana (1) bila arus kas operasi negatif dan (0) bila arus operasi positif.

$\mathrm{DCFOt} \quad=$ Arus kas operasi dibagi dengan total aset perusahaan

DCFO*CFO = Interaksi antara variabel dummy dengan arus kas operasi

$\mathrm{CON}_{4 \mathrm{t}} \quad=$ Proksi konservatisme, Bila koefisien positif menunjukan perusahaan menerapkan akuntansi konservatif.

5. Non Operating Acruals mengacu pada Givoly and Hayn (2000). Non Operating Acruals diperoleh dari pengurangan antara Total Acruals dengan Operating Acruals. Dinotasikan dengan rumus sebagai berikut :

$$
\text { NOACC }=\text { TACC-OACC }
$$

Keterangan :
NOACC $=$ Non Operating Acrual
TACC $=$ Total Accrual
$=($ laba bersih + depresiasi $)$-arus kas operasi
OACC = Operating accrual
$=\Delta$ piutang usaha $+\Delta$ persediaan $+\Delta$ Biaya dibayar dimuka $-\Delta$ utang usaha- $\Delta$ utang pajak

Perusahaan dengan Non Operating Acrual negatif dikatakan menerapkan akuntansi koservatif.

Pengukuran konservatisme akuntansi di atas didasarkan pada pendekatan yang digunakan oleh para peneliti dibidang konservatisme akuntansi. Pengukuran di atas tidak saling meniadakan. Artinya dalam satu penelitian peneliti dapat menggunakan beberapa model pengukuran kkonservatisme akuntansi. Pengukuran konservatisme 
akuntansi dengan satu metoda dapat memberikan hasil yang berbeda apabila dibandingkan dengan metoda yang lain.

\section{KESIMPULAN}

Penelitian ini membahas tentang beberapa metoda yang digunakan untuk mengukur tingkat konservatisme akuntansi dalam sebuah perusahaan. Dengan mengacu pada telaah literatur dari penelitian tentang konservatisme akuntansi dapat disimpulkan bahwa tingkat konservatisme akuntansi dalam sebuah perusahaan dapat diukur dengan beberapa pendekatan antara lain: 1) model pasar, 2). model market to book ratio, 3) pendekatan laba operasi, 4) pendekatan akrual arus kas, 5) non operating acrual. Penelitian ini tidak lepas dari beberapa keterbatasan. Penelitian ini merupakan sebuah telaah literatur. Penelitian selanjutnya dapat dilakukan dengan menggunakan data empiris dan melakukan perbandingan ketepatan pengukuran konservatisme dengan beberapa metoda. Penelitian selanjutnya yang akan menguji tentang konservatisme akuntansi disarankan untuk menggunakan beberapa metoda pengukuran konsevatisme akuntansi yang disajikan dalam penelitian ini.

\section{DAFTAR PUSTAKA}

Basu, S. 1997. The conservatism principle and the asymmetric timeliness of earnings. Journal of Accounting \& Economics 24 (December): 3.37.

Fala, Dwiyana Amalia.S. 2007. Pengaruh Konservatisma Akuntansi Terhadap Penilaian Ekuitas Perusahaan Dimoderasi Oleh Good Corporate Governance. SNA X : Ikatan Akuntansi Indonesia

Givoly, Dan dan Hayn, Carla. 2000. The changing time-series properties of earnings, cash fows and accruals:Has finanancial reporting become more conservative? Journal of Accounting and Economics 29 (2000) 287-320

Kiryanto dan Suprianto,Edy. 2006. Pengaruh Moderasi Size Terhadap Hubungan Laba Konservatisma Dengan Neraca Konservatisma. SNA IX : Ikatan Akuntansi Indonesia

Paek, Wonsun, Chen.Lucy.H, and Sami. H. 2007. Accounting Convervatism, earning Persistance and Pricing Multiples on Earning. Available online at http:// www.ssrn.com, diunduh tanggal 4 Januari 2010.

Penman, Stephen.H dan Xiao-Jun Zhang. 2002. Accounting Conservatism, the Quality of Earnings, and Stock Returns. The Accounting Review, Vol. 77. No. 2 April 2002, pp. 237-264.

Wardhani, Ratna. 2008. Tingkat Konservatisme Akuntansi Di Indonesia Dan Hubungannya Dengan Karakteristik Dewan Sebagai Salah Satu Mekanisme Corporate Governance. SNA 11 : Ikatan Akuntan Indonesia. 
Watts, Ross.L. 2003. Conservatism in Accounting Part I: Evidence and Research Opportunities. available online at http:// www.ssrn.com, diunduh tanggal 7 Julli 2009.

Widay. 2004. Faktor-Faktor Yang Mempengaruhi Pilihan Perusahaan Terhadap Akuntansi Konservatif. SNA VII. Ikatan Akunatnsi Indonesia

Widodo lo, Eko.2005. Pengaruh Tingkat Kesulitan Keuangan Perusahaan Terhadap Konservatisme Akuntansi. SNA VIII : Ikatan Akuntansi Indonesia 